\title{
Bioaccumulation of Total Hydrocarbon and Heavy Metals in Body Parts of the West African Red Mangrove Crab (Goniopsis pelii) in the Niger Delta, Nigeria
}

\author{
A.O. Numbere* \\ Department of Animal and Environmental Biology, University of Port Harcourt, Choba, Nigeria. \\ *aroloyen@yahoo.com
}

Keywords: Goniopsis pelii, Rhizophora, heavy metals, bioaccumulation, Niger Delta, hydrocarbons

\begin{abstract}
This study is based on bioaccumulation of total hydrocarbon (THC) and heavy metals in body parts of the West African red mangrove crab (G. pelii), which inhabit polluted mangrove forests. Thirty crabs were captured in October, 2018 and sorted into male and female. Their lengths and widths were measured, and body parts dismembered and oven-dried at $70^{\circ} \mathrm{C}$ for 48 hours. Physicochemical analysis for Cadmium $(\mathrm{Cd})$, Zinc $(\mathrm{Zn})$, Lead $(\mathrm{Pb})$ and THC was measured by spectrophotometric method using HACH DR 890 colorimeter (wavelength $420 \mathrm{~nm}$ ) and microwave accelerated reaction system (MARS Xpress, North Carolina) respectively. There was no significant difference $(\mathrm{P}>0.05)$ in THC and heavy metals in the body parts of crabs. However, Zinc was highest in claw $(993.4 \pm 91.3 \mathrm{mg} / \mathrm{l})$ and body tissues $(32.5 \pm 1.9 \mathrm{mg} / \mathrm{l}), \mathrm{Pb}$ was highest in carapace (34.6 \pm $2.8 \mathrm{mg} / \mathrm{l})$ and gill $(151.9 \pm 21.6 \mathrm{mg} / \mathrm{l})$ while THC was highest in intestine $(39.5 \pm 2.9 \mathrm{mg} / \mathrm{l})$ and gut $(52.4 \pm 13.4 \mathrm{mg} / \mathrm{l})$. The order of concentration is $\mathrm{Zn}>\mathrm{Pb}>\mathrm{THC}>\mathrm{Cd}$. Male crabs had slightly higher THC and heavy metal concentration than female crabs probably because of their large size. There is negative correlation between carapace area and THC concentration $(R=-0.246)$, meaning THC decreases with increasing carapace size. Internal parts of crab had higher THC and heavy metal concentration than external parts. These results show that there is high bioaccumulation of THC and heavy metals in crab, which is above WHO/FAO standard. This implies that the crabs are unfit for human consumption. The smaller the crab the better it is for consumption in terms of bioaccumulation of pollutants.
\end{abstract}

\section{Introduction}

Mangrove forest of the Niger Delta is the largest in Africa and the third largest in the world [1]. It is a biodiversity hot spot and often described as the supermarket of the sea [2]. A variety of organisms dwell within the forest ranging from vertebrates to invertebrates, including ground and tree dwellers. The vertebrates include fishes, guinea fowls, birds, and monkeys. The invertebrate population include: crabs, periwinkle, oyster, and insects. Insects are the most populous invertebrates in the mangrove forest [3]. These organisms form the food chain of the mangrove ecosystem, and each depend directly or indirectly on one another for existence. At the top of the food chain are humans who feed on some of the species below the food chain. Crabs play critical role by acting as the link between ground and tree-dwelling organisms. They climb the trees and cut the leaves, which fall to the ground to be fed upon by fish and other aquatic organisms. Humans catch and consume fish, crab and other aquatic organisms, which predispose them to contamination. Litter fall and litter accumulation on the forest floor make the mangrove to be highly productive [4], and rich in microbial activities [5]. The leaf litter is consumed by crabs, which hide the leaves in the soil to decompose and reduce the tannin content.

However, crabs are described as enemy number one of mangroves [6]. This is because their consumption of mangrove propagules affect natural regeneration and influence distribution of mangrove species across intertidal zones [7]. Crabs also form obligatory relationship with mangrove by depending on them directly for survival [8]. Crabs of the family Grabsidae, most common in the Indo-West Pacific region, live directly and forage on mangrove tree canopy [7]. Most crabs climb mangrove trees to escape predators and feed on the seeds [9]. In East Africa, Sesarma leptosome is 
an active climber and can reach the top of the tallest trees to feed on mangrove materials [10]. Crab preference for mangrove depends on the age [11], and the nutritional value of the trees [12, 13]. Mangrove leaves are not nutritious per se, but could influence the survival, growth and reproduction of crabs.

The dominant crab species in the mangrove forest of the Niger Delta is the West African red mangrove crab. They feed on mangrove leaves and propalgules on the forest floor and on the trees. They climb the trees when there is high tide and come down to forage when there is low tides [1]. They are mostly found in red mangroves (Rhizophora spp) that is why they are called the red mangrove crab. The problems of mangroves are over-exploitation, clear-cutting and pollution [14]. Although mangrove forest is highly productive, it is also a recipient of crude oil spillages from pipelines that convey petrochemical products from Port Harcourt Refinery (PHRC) to Okrika Jetty [15]. Oil spillage has made the forest floor to be in a constant state of hydrocarbon pollution, leading to a steady increase in heavy metal concentration in soil, flora and fauna of the mangrove forest [1618]. Metals taken up by the roots get concentrated in mangrove leaves. Conversely, no correlation was found between metal concentration in mangrove leaves and in mangrove soils in the Gulf Coast [19]. Low levels of metal in mangrove leaves are caused by bio unavailability or exclusion of metals and the physiological adaptation of the plant to metal accumulation [20]. Not all metals are detrimental to mangroves, but some are important to their growth and development; for example, Nitrogen and phosphorous, are two major nutrients that are common in mangrove forests. Deposition of sewage and organic product in mangrove swamp do not affect the biomass, density and community structure of benthic micro fauna [21]. Nonetheless, areas of swamp exposed to sewage have more sediment mixing than areas not exposed [22]; on the contrary, sewage discharge can kill the pneumatophores of Avicennia marina as was observed in the Red Sea [23]. Increased contamination of mangrove by waste makes them to be less resistant to Nypa palm (Nypa fruticans) invasion, which further compounds the problems caused by hydrocarbon pollution. Hydrocarbon pollution from oil and gas exploration destroys and reduces the global population of mangrove ecosystem [24]. Oil pollution causes the defoliation of mangrove leaves and reduces their ability to effectively carry out photosynthesis; furthermore, hydrocarbon pollution affects the stability and sustainability of mangroves.

These pollutants get into the bodies of mangrove dwellers through bioaccumulation. Long term presence of crabs and other species in the polluted environment had made them to survive and adapt to the polluted condition [25]. However, it is not known whether the THC and heavy metals in the body of crabs are beyond tolerable level for human consumption [26]. This is because heavy metals can be transferred to humans through bioaccumulation and biomagnifications [27]. It is therefore, important to study the levels of these pollutants in crabs to check whether they are within acceptable standard. Since the crabs have the habit of moving between ground and tree they form soil-organismplant pathway for the transmission of heavy metals to humans [28]. Amongst the heavy metals, three were chosen for this study (i.e. Cadmium, Zinc and Lead), because experimental evidence had shown that in cationic forms i.e. $\mathrm{Cd}^{2+}, \mathrm{Zn}^{2+}$ and $\mathrm{Pb}^{2+}$ can cross the gill epithelium of crustaceans to compete with osmoregulatory function [29]. The pollutants are then transferred to humans when the crabs are eaten. The objectives of the study, therefore, are: (1) to determine the THC and heavy metal concentrations in the body parts of crabs; (2) to compare the THC and heavy metal concentration in male and female crabs; (3) to determine the part of the body (i.e. internal and external) with higher bioaccumulation and to show the relationship between crab carapace area and THC concentration.

\section{Materials and Methods}

\section{Study Area}

The study area is mangrove forest in Okrika ( $\left.4^{\circ} 43.509^{\prime}, E 7^{\circ} 05.259^{\prime}\right)$, situated in the Niger Delta region of Nigeria (Fig. 1). It has humid climate with rainfall occurring almost all throughout the year. There are two major seasons, wet (February-September) and dry (October-January) seasons. The area is a biodiversity hot spot and a crude oil evacuation point. It has a tropical monsoon climate, 
and rainfall occurs all through the year with a mean annual rainfall of $3567.4 \mathrm{~mm}^{-1}$ year $^{-1}$ [30]. The mean monthly temperature ranges between 26 and $30^{\circ} \mathrm{C}$. The area has an average of seven hours of sunlight per day with high rate of photosynthetic activity, which makes the trees to be evergreen all year round. The soil is a mixture of root and plant litter called chikoko in the locality. Detail description of study area is given in [1]. This study was conducted between $1^{\text {st }}$ to $2^{\text {nd }}$ October, 2018 .

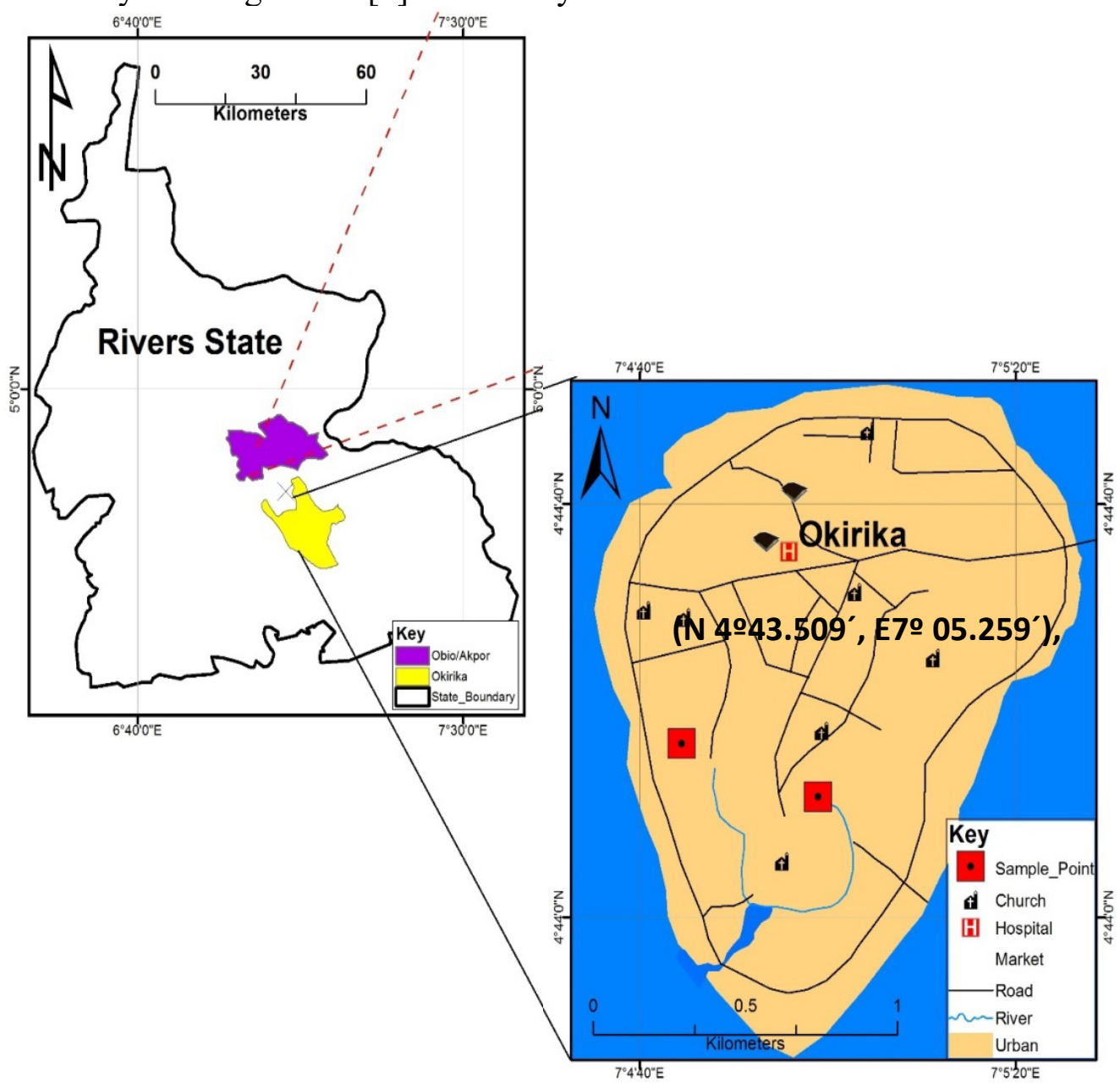

Figure 1. Map of study area indicating the area of crab collection in Okrika, Rivers State, Nigeria.

\section{Description of study species}

The West African red mangrove crab (G. pelii) is not the only crab species present in the mangrove forest, but they are the most dominant species (Fig. 2a). Other crab species found in the mangrove forest, are fiddler crabs, ghost crabs and land crabs. Nevertheless, G. pelii is the most prominent and has the highest population ( 5-10 per tree) with over 1000 crabs in a $20 \mathrm{~m} \times 20 \mathrm{~m}$ plot in the mangrove forest. They are highly skillful in tree-climbing [31], which helps them to evade capture by ground predators. They originated from the Atlantic coast of Africa, and have distinct black coloration at their dorsal surface and a white coloration at the ventral surface. They are decapods with four hairy pairs of legs (pelii) and one non hairy pair of powerful pincers with sharp edges used to cut objects (Fig. 2b). This shearing ability makes them to leave behind a trail of distinct cut impressions on mangrove leaves. The crabs are omnivores, and feed on both plant and animal matter. In addition, they are amphibious and survive on both land and water. Nigeria and Cameroun share the same boundary and have similar mangrove and crab species [32]. 


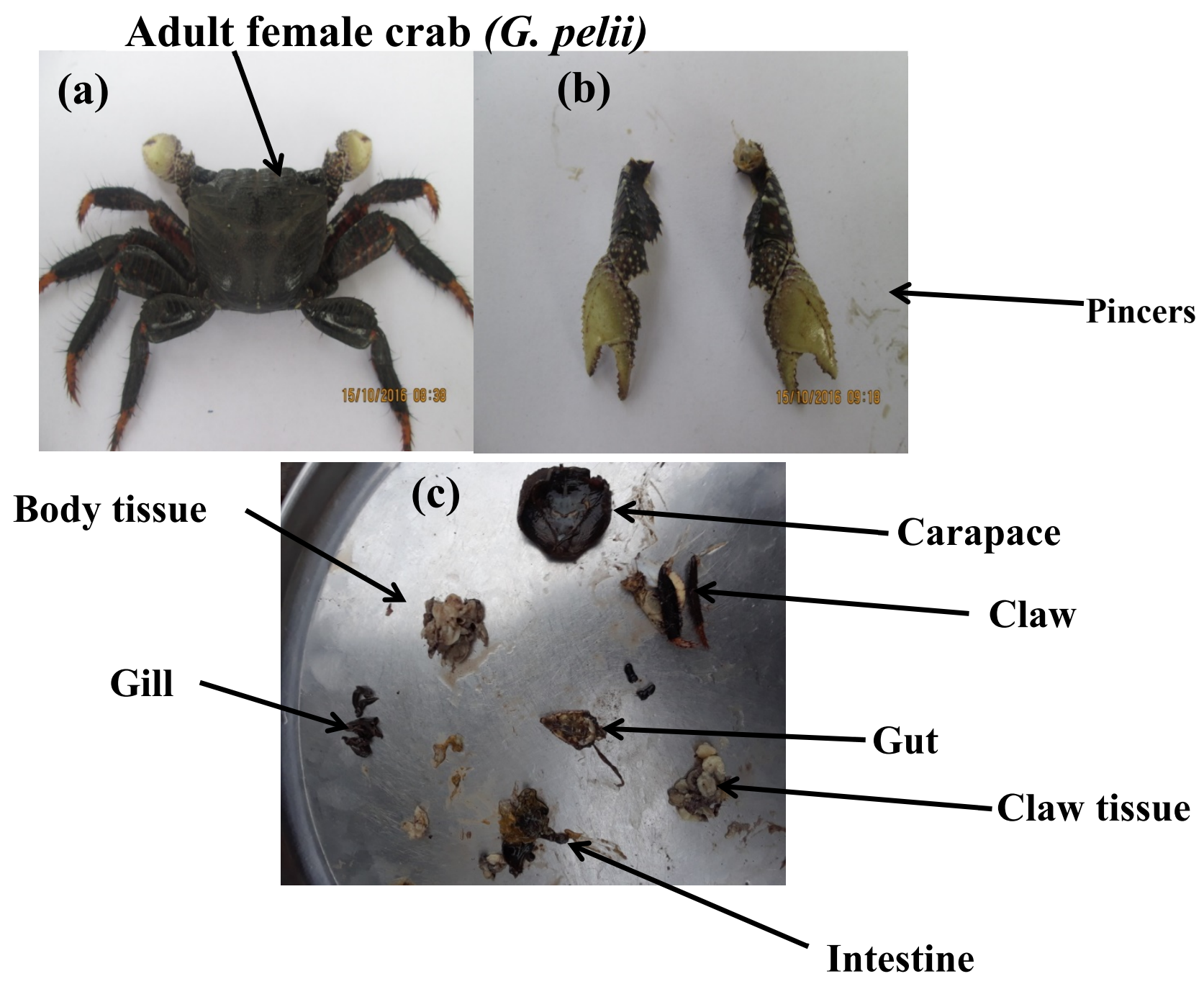

Figure 2. West African red mangrove crab (a) an adult female crab (G. pelii) captured in the mangrove forest of Okrika, (b) pincers of crab used for grabbing and shearing objects and for defense and (c) dissected parts of crab showing the internal and external parts.

\section{Sample collection}

Thirty crabs were captured alive by hand on the trees, and on the forest floor and placed in a container. They were transported to the laboratory where they were sorted into males and females using standard gender selection characteristics following the example of [33]. They were measured with meter rule before they were dissected into various parts for laboratory analysis (Fig. 2c). Their tissues, organs and body parts were placed in aluminum foil and oven dried at $70 \mathrm{C}^{\circ}$ for 48 hours to get rid of moisture. Metal concentration from the tissues was determined by the procedures of [34].

\section{Laboratory Analysis}

\section{Procedure of total hydrocarbon content analysis}

It involved the use of spectrophotometric method using the HACH DR 890 calorimeter (wavelength $420 \mathrm{~nm}$ ). The samples were crushed and $2 \mathrm{~g}$ of the crushed sample was weighed into a glass beaker and $20 \mathrm{ml}$ of hexane was added, and with the aid of a glass rod, the mixture was homogenized by stirring. Afterwards, the sample was filtered in a glass funnel packed with cotton wool, silica gel and anhydrous sodium sulphate. After this, $10 \mathrm{ml}$ of the filtered organic extract was transferred into a $10 \mathrm{ml}$ sample curvet and inserted into the calorimeter. The detection limit for THC is $0.01 \mathrm{mg} / \mathrm{l}$. 


\section{Heavy metal analysis}

Heavy metal extraction followed the example of [35]. Aliquots of $0.25 \mathrm{~g}$ of air dried sediment samples were weighed into a Teflon inset of a microwave digestion vessel and $2 \mathrm{ml}$ concentrated (90\%) nitric acid (Sigma-Aldrich, Dorset, UK) were added. The metals were extracted using a microwave accelerated reaction system (MARS Xpress, CEM Corporation, Matthews, North Carolina) at $1500 \mathrm{~W}$ power $(100 \%)$, ramped to $175^{\circ} \mathrm{C}$ in $5.5 \mathrm{~min}$, held for $4.5 \mathrm{~min}$, and allowed to cool down for $1 \mathrm{~h}$. The cool digest solution was filtered through the Whatman 42 filter paper and made up to $100 \mathrm{ml}$ in a volumetric flask by adding de-ionized water. All chemicals and reagents used were of analytical grade and of highest purity possible. Analytical blanks were prepared with each batch of the digestion set and analyzed (one blank for every set of 6 samples) in the same way as the samples. The detection limit for the three metals analyzed in $\mathrm{mg} / \mathrm{l}$ i.e. Zinc, Cadmium and Lead is $0.001,0.001$ and 0.002 respectively.

\section{Statistical analysis}

An analysis of variance (ANOVA) was conducted to determine whether there was a significant difference in THC and heavy metal concentration in the different body parts of the crabs. The data was first $\log$ transformed to ensure that they were normal and the variances were equal. Since the crab samples were small in number $(\mathrm{n}=30)$, a non-parametric separate variances (Welch's) t-test was performed to test the null hypothesis that the carapace area is the same for both male and female $\mathrm{crab}[36]$. For the relationship between THC of the carapace and carapace area, a Pearson's correlation coefficient test was performed where the null hypothesis states that the correlation coefficient of carapace area and THC concentration equals zero. Bar graphs were then used to illustrate the significance and difference in concentration in body parts and between male and female crabs. All analyses were done in [37].

\section{Results}

\section{THC and heavy metal concentration in body parts of crabs (G. pelii)}

The result (Table 1; Fig. 3) indicates that there is no significant difference $\left(\mathrm{F}_{1,49}=1.32, \mathrm{P}>\right.$ 0.05 ) in THC and heavy metal concentration in the body parts of crab (G. pelii). However, Zinc had the highest overall concentration $(993.37 \pm 91.3 \mathrm{mg} / \mathrm{l})$ in claw tissue followed by the gill $(100.3 \pm$ $15.7 \mathrm{mg} / \mathrm{l})$ and the gut $(51.5 \pm 13.5 \mathrm{mg} / \mathrm{l})$. This is in agreement with the results of [38] who revealed that Zinc concentration was the highest in fish gill, muscle and liver. Similarly, the highest Cadmium concentration was also recorded in claw tissue $(14.7 \pm 13.3)$ followed by body tissue $(14.3 \pm 0.7 \mathrm{mg} / 1)$. Lead concentration is highest in gill $(151.9 \pm 21.6 \mathrm{mg} / \mathrm{l})$ followed by claw tissue $(146.9 \pm 13.1 \mathrm{mg} / \mathrm{l})$. The order of heavy metal and THC concentration in the body part of G. pelii is $\mathrm{Zn}>\mathrm{Pb}>\mathrm{THC}>\mathrm{Cd}$; and concentrations in G. pelii generally followed the order of claw tissue $>$ gill $>$ gut $>$ body tissue $>$ intestine $>$ carapace $>$ pincers (Table 1). For an average adult fish ( $60 \mathrm{~kg}$ body weight), the provisional tolerable daily intake for lead and zinc are $0.2 \mathrm{mg}$ and $60 \mathrm{mg}$ [39]. The range of Lead in crabs in this study is between $12-147 \mathrm{mg} / 1$, which is far above the standard limit of $0.5 \mathrm{mg} / 1$ for crab. In contrast, the Zinc levels were all below standard limit (i.e. $40 \mathrm{mg} / \mathrm{l}$ ) apart from claw tissue (993.37 $\pm 91.3 \mathrm{mg} / \mathrm{l})$, gill $(116.00 \pm 15.67 \mathrm{mg} / \mathrm{l})$ and gut $(51.5 \pm 13.5)$ that were high. The total hydrocarbon content (THC) was highest in gut $(52.4 \pm 13.4 \mathrm{mg} / \mathrm{l})$ followed by intestine $(39.5 \pm 2.9 \mathrm{mg} / \mathrm{l})$ and carapace $(20.83 \pm 2.3 \mathrm{mg} / \mathrm{l})$. 
Table 1. Mean levels of total hydrocarbon content (THC) and heavy metals \pm 1 SE in different body parts of crab (G.pelii) in Okrika, Niger Delta Nigeria.

\begin{tabular}{lllll}
\hline Body parts & \multicolumn{4}{c}{ Metals (mg/l) } \\
\cline { 2 - 5 } & THC & Zn & Cd & Pb \\
\hline Carapace & $20.8 \pm 2.3^{\mathrm{c}}$ & $14.3 \pm 2.3^{\mathrm{f}}$ & $3.1 \pm 0.8^{\mathrm{c}}$ & $34.6 \pm 2.8^{\mathrm{c}}$ \\
Claw tissue & $10.4 \pm 1.2^{\mathrm{e}}$ & $993.4 \pm 91.3^{\mathrm{a}}$ & $14.7 \pm 1.3^{\mathrm{a}}$ & $146.9 \pm 13.1^{\mathrm{b}}$ \\
Intestine & $39.5 \pm 2.9^{\mathrm{b}}$ & $20.7 \pm 1.1^{\mathrm{e}}$ & $2.8 \pm 1.5^{\mathrm{c}}$ & $11.9 \pm 1.8^{\mathrm{f}}$ \\
Pincers & $5.0 \pm 0.5^{\mathrm{f}}$ & $9.9 \pm 5.9^{\mathrm{g}}$ & $2.6 \pm 0.7^{\mathrm{c}}$ & $34.5 \pm 3.5^{\mathrm{c}}$ \\
Gill & $4.0 \pm 0.5^{\mathrm{f}}$ & $100.3 \pm 15.7^{\mathrm{b}}$ & $6.7 \pm 2.3^{\mathrm{b}}$ & $151.9 \pm 21.6^{\mathrm{a}}$ \\
Gut & $52.4 \pm 13.4^{\mathrm{a}}$ & $51.5 \pm 13.5^{\mathrm{c}}$ & $2.6 \pm 0.3^{\mathrm{c}}$ & $19.8 \pm 7.6^{\mathrm{e}}$ \\
Body tissue & $13.7 \pm 2.0^{\mathrm{d}}$ & $32.5 \pm 1.9^{\mathrm{d}}$ & $14.3 \pm 0.7^{\mathrm{a}}$ & $23.6 \pm 1.1^{\mathrm{d}}$ \\
\hline
\end{tabular}

Different letters on column indicate significant differences $(\mathrm{P}<0.05)$

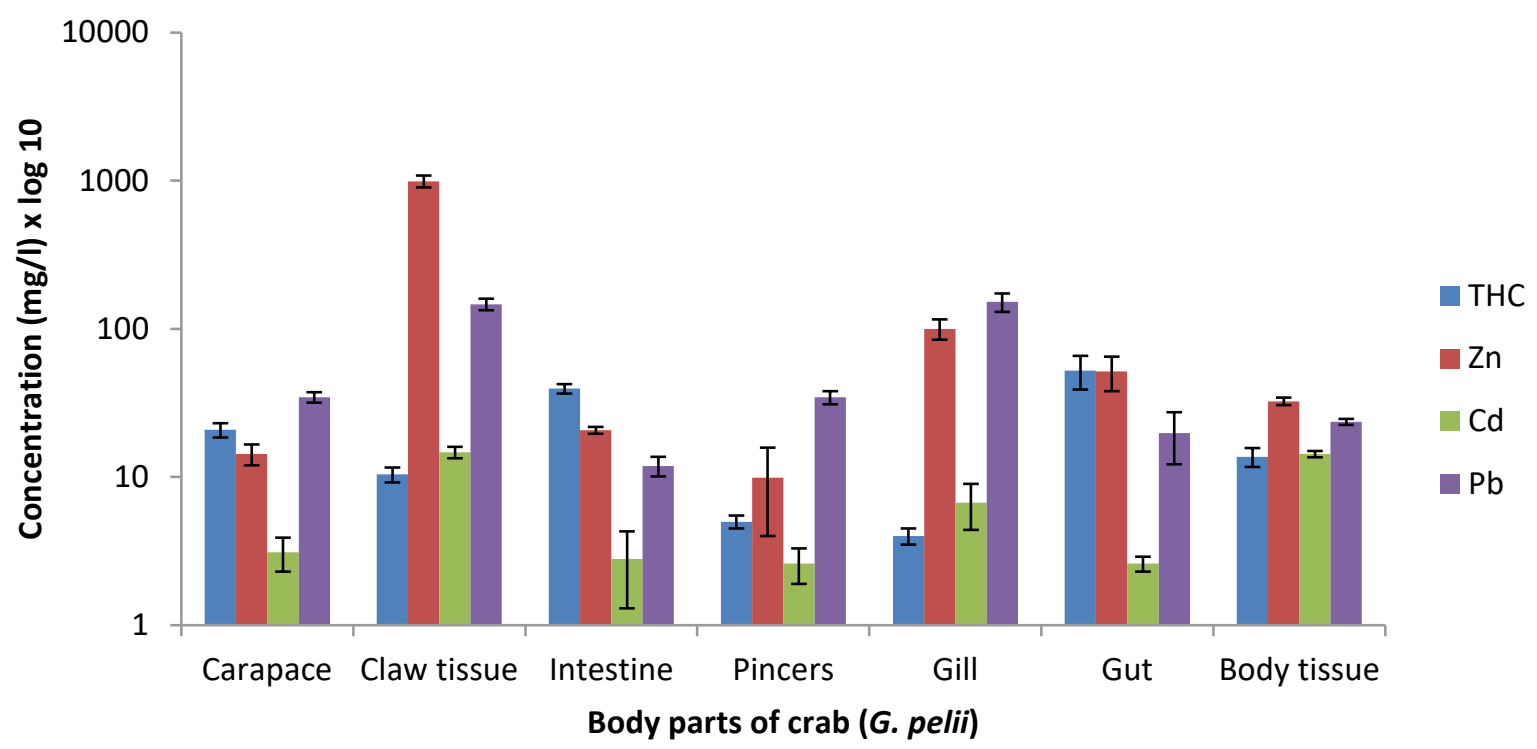

Figure 3. Concentration of some heavy metals (Cadmium, Lead and Zinc) and THC in different body parts of crab (G.pelii) captured in Okrika Jetty, Niger Delta, Nigeria. Vertical lines show \pm 1 standard error of the mean.

There was no significant difference in heavy metal and THC concentration in male and female crabs $\left(\mathrm{F}_{1,54}=1.26, \mathrm{P}>0.05\right.$; Fig. 4$)$.

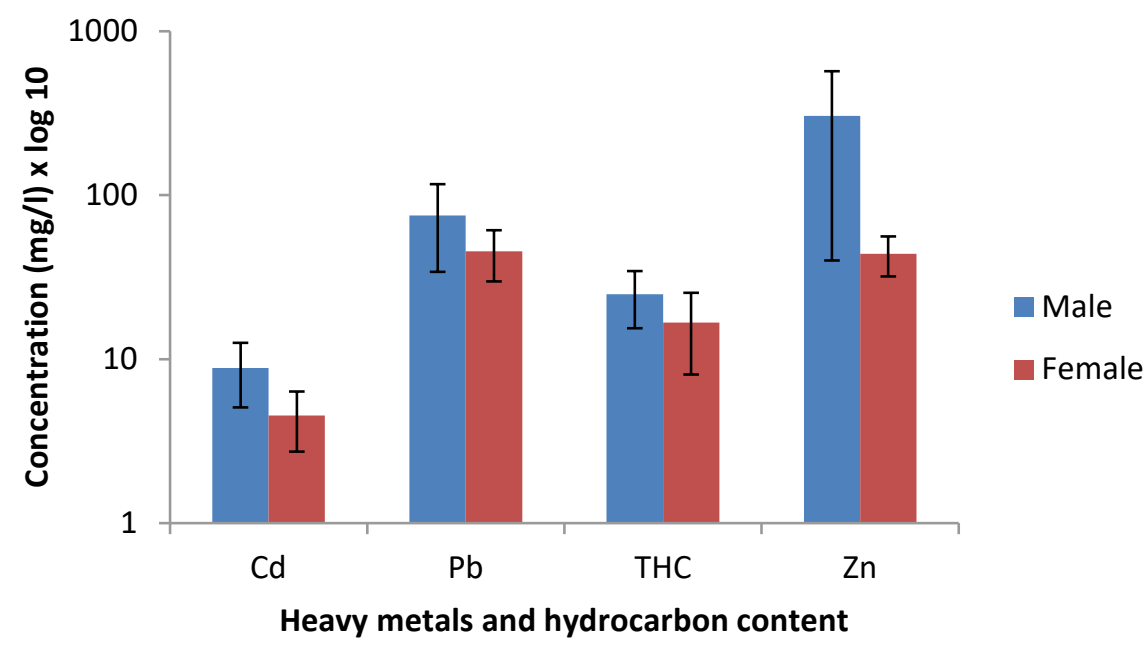

Figure 4. Levels of $\mathrm{Cd}, \mathrm{Pb}, \mathrm{THC}$ and $\mathrm{Zn}$ in female and male crab (G. pelii) captured in Okrika, Niger Delta, Nigeria. Both sexes show no statistical significance $(P>0.05)$ in heavy metal and hydrocarbon concentration Vertical lines show \pm 1 standard error of the mean. 


\section{Carapace size relationship and THC concentration in male and female crabs}

The result for the Welch test indicates that carapace area of male crab did not differ significantly from that of the females $(t=-1.708, d f=25.654, P=0.1)$. However, male crabs have slightly larger carapace than female carapace (Table 2).

Table 2. Comparison of mean carapace area and total hydrocarbon concentration (THC) $\pm 1 \mathrm{SE}$ in crab (Goniopsis pelii) captured in Okrika, Niger Delta, Nigeria.

\begin{tabular}{lllll}
\hline Sex & $\begin{array}{l}\text { Size } \\
\text { range }\end{array}$ & $\begin{array}{l}\text { Mean carapace area } \\
\left(\mathbf{c m}^{\mathbf{2}}\right)\end{array}$ & $\begin{array}{l}\text { THC concentration } \\
(\mathbf{m g} / \mathbf{k g})\end{array}$ & P-value \\
\hline Male & Large & $55.1 \pm 3.4$ & $18.8 \pm 0.4$ & $>0.05$ \\
Female & Large & $53.4 \pm 7.4$ & $21.4 \pm 0.6$ & $>0.05$ \\
Male & Medium & $38.6 \pm 8.6$ & $18.4 \pm 0.4$ & $>0.05$ \\
Female & Medium & $35.9 \pm 3.2$ & $20.9 \pm 0.6$ & $>0.05$ \\
Male & Small & $28.5 \pm 2.1$ & $19.1 \pm 0.4$ & $>0.05$ \\
female & Small & $23.9 \pm 0.8$ & $22.1 \pm 0.7$ & $>0.05$ \\
\hline
\end{tabular}

The correlation between carapace area and THC concentration was negative, meaning that there was a weak correlation $\left(r=-0.246, t_{28}=-1.345, P>0.05\right)$. However, male carapace had slightly higher concentration of THC than the female carapace (Fig. 4). This is supported by the correlation, which shows that as the area of the carapace increases the THC decreases.

\section{THC and heavy metal concentration in internal and external parts of crab}

There is no significant difference in overall THC and heavy metal concentration in internal and external parts of the crab $\left(\mathrm{F}_{1,54}=0.87, \mathrm{P}>0.05\right)$. However, the concentration of Zinc and Cadmium varied significantly (Fig. 5).

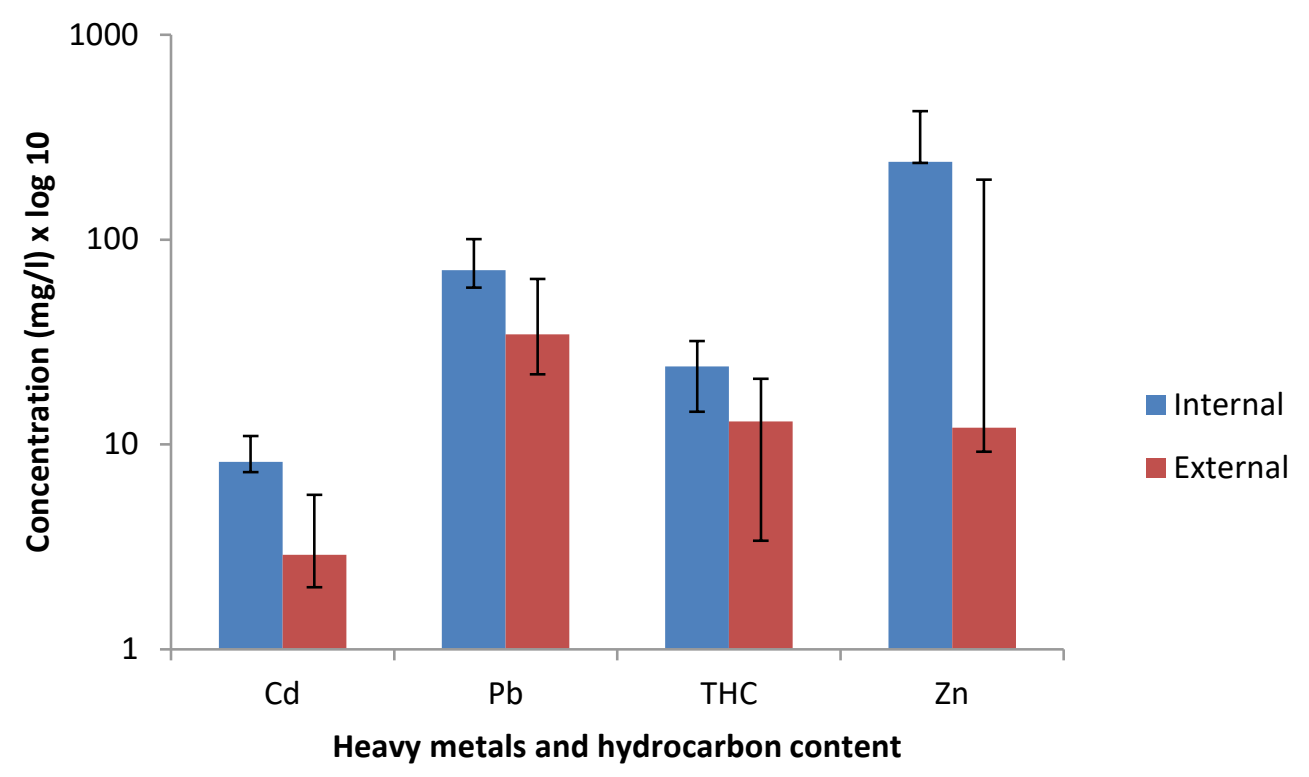

Figure 5. Levels of $\mathrm{Cd}, \mathrm{Pb}, \mathrm{THC}$ and $\mathrm{Zn}$ in internal and external body parts of crab (G.pelii captured in Okrika, Niger Delta. Both body parts show no statistical significance $(\mathrm{P}>0.05)$ in heavy metal and hydrocarbon concentration. Vertical lines show \pm 1 standard error of the mean. 


\section{Discussion}

\section{THC and heavy metal concentration in body parts of crabs (G.pelii)}

Aquatic organisms take up and accumulate toxic metals from their environment through their gills or body surface, and from their diet through their intestine. Unlike fishes (teleost) which drink water [40], crustaceans e.g. crab don't, but take in toxic metals through their gills when they are submerged in water [41]. Gills provide selective interface between the external and the internal environment, which puts them in constant danger of accumulating toxic substances from their environment. Large surface area and permeability of the gills create counter current via the flow of water and hemolymph to facilitate gaseous exchange, which accelerate the uptake of heavy metals [42]. The toxic metals when taken across the gills are transported directly to the internal organs such as the gut and the muscles. In the same vein, the chitinous membranes (e.g. carapace) are efficient in binding to trace metals. This can lead to the transport and lodging of heavy metals in exoskeleton of crabs [43]. This study is in agreement with [44] whose study revealed that individual total metal load was higher in crab shell than other tissues. Similarly, claw tissue had the highest zinc concentration because it is used for walking and most time buried in the polluted sediments in the mangrove forest. There is variation of heavy metal accumulation between organs in crustaceans [45]. This is shown by the order of concentration of heavy metals and THC i.e. claw tissue $>$ gill $>$ gut $>$ body tissue $>$ intestine $>$ carapace $>$ pincers. Pincers are the least to accumulate heavy metals and THC because external parts, such as the exoskeleton have lesser concentration than the internal organs (Fig. 5).

Zinc had high concentration in this study because it is a metal that occurs naturally in the earth crust. It enters the mangrove forest soil through waste from industrial plant. Zinc is used for galvanizing steel and for preparing alloys of crude oil pipelines, which passes through the mangrove forests. Zinc is also used in boat building, and when it corrodes in the saline water permeates into the mangrove forest.

The gill and gut are the internal organs used for respiration and digestion respectively, thus it depends on external intake of air and food substances along with pollutants. Moreover the gills of crustaceans is a multi-purpose organ, and a site for a number of physiological processes such as ion transport, which is the basis for hemolymph osmoregulation; acid-base balance, and ammonia excretion [46]. The gill is also the site by which many toxic metals are taken up by aquatic organisms, and therefore it plays an important role in the toxicology of these species [46]. The heavy metal concentration of this study were mostly above the FAO/WHO [39] standard, which means the crabs (G. pelii) in the study locality are not fit for human consumption because they can lead to food poisoning and health complications. The high heavy metal is because the area of study is highly polluted as a result of constant spillages from crude oil pipelines. Although, G. pelii is not a prominent food delicacy, it is still consumed by some persons in the area.

\section{Carapace area relationship and THC concentration in male and female crabs}

The carapace size is used in morphometric studies to determine the traits of the male and female crabs. The hard exoskeleton is a store house for minerals absorbed from food. The males are bigger (Table 2), and more colorful than the females. The males have a bigger pincers, which they use to attract the females during courtship. The abdomen of the male is enlarged, narrow and triangular while the females' abdomen is broad and narrow. Nevertheless, the most convincing difference between the male and the female is the possession by the females of egg pouch under their abdomen. The male crabs are territorial and use their large size to scare away intruders.

THC concentration is not significantly different between male and female crabs. Although males have slightly higher THC than female crabs probably because of their large size, which makes them to have large surface areas to volume in substance absorption (Table 2). In contrast, female reproductive cycle may also affect the accumulation of toxic metals from the environment [46]. For instance, the habit of female crabs burrowing and spawning their young ones inside mangrove swamp during gestation period may predisposed them to absorbing more pollutants and contaminants from the soil. 


\section{Concentration in different areas of the crab (internal vs. external parts)}

The high concentration of heavy metals and THC in the internal parts as compared to the external parts is because of more bioaccumulation of toxic materials that are transmitted from the outside via the gills into the internal organs. This study is in agreement with [47] who found out that average Cadmium concentration was more in soft tissues than in exoskeleton, while the reverse is the case for average Lead concentration. For instance, Long term exposure to sub-lethal concentrations of Zinc and Cadmium induce the impairment of respiratory functions in crab, Cancer pagurus [48]. Similarly, the effect of Lead toxicity on branchial cell of the gills of Callinectes ornatus was revealed by [49]. This revelation shows that the crabs are detrimental to human when consumed due to the toxicity and teratogenic effect of Lead and other heavy metals. This study showed that the internal part of the crab that is often consumed has higher concentration of THC and heavy metal than the external parts that is often discarded. Almost all the parts have concentrations that are above the permissible limit (Table 1).

\section{Conclusion}

The size, sex, and body parts of crabs are important aspect of bioaccumulation of THC and heavy metals. Large-sized male crabs have higher THC and heavy metal bioaccumulation. Internal parts of crabs too store more pollutants than external parts. Although statistically they are not significant, but physiologically small concentrations of heavy metals may have magnified effect in the body. The high bioaccumulation of pollutants in the various body parts of crabs $(G$. pelii) in the study show that the crabs are not fit for human consumption. This is because the poisonous metals get magnified as they go up the food chain making them harmful to humans. Crabs directly consume pollutants along with their food while feeding on smaller organisms on the forest floor. Results of this study indicate that it is important to investigate and monitor the THC and heavy metal concentrations in the body parts of other organisms that reside in the mangrove forest. This will help prevent contamination through direct or indirect consumption of forest product (e.g. food, medicinal herbs and other ecosystem services) that are contaminated.

\section{Conflict of Interest}

The author declares that there is no conflict of interest.

\section{Acknowledgement}

The author wishes to thank the graduate students in Dr. Numbere's lab, especially Miss Ngozi Oparanozie for assistance in sample collection.

\section{References}

[1] A.O. Numbere, Impact of hydrocarbon pollution on the mangrove ecosystem of the NigerRiver Delta, Nigeria. PhD dissertation, Saint Louis University, Saint Louis, Missouri (2014).

[2] A.C. Ibe, The Niger Delta and sea level rise: In sea-level rise and coastal subsidence, Springer, Dordrecht, 1996, pp. 249-267.

[3] L.A. Dyer et al., Host specificity of Lepidoptera in tropical and temperate forests, Nature. 448 (2007) 696-699.

[4] A.O. Numbere, G.R. Camilo, Effect of pollution and seasonal changes on litter fall and accumulation in mangrove forest (Rhizophora species) of the Niger Delta, Nigeria, J. Environ. Sci. Tech. 11(2) (2018) 86-94. 
[5] A.O. Numbere, G.R. Camilo, Mangrove leaf litter decomposition under mangrove forest stands with different levels of pollution in the Niger River Delta, Nigeria. Afr. J. Ecol. 55 (2017) 162-167.

[6] J.O. Watson, Mangrove forests of the Malay Peninsula, Malayan Forest Records. 6 (1928) 1275.

[7] T.J. Smith, Effects of seed predators and light level on the distribution of Avicennia marinaForsk.in tropical tidal forests, Estuarine Coastal Shelf Science. 25 (1987) 43-52.

[8] W.L. Vergara-Filho, J.R.P. Alves, N.C. Maciel, Diversity and distribution of crabs (Crustacea, Decapoda, Brachyura) in mangroves of Guanabara Bay, Rio de Janeiro, Brazil,in: B. Kjerfve, L.D. Lacerda, S. Diop (Eds.), Mangrove Ecosystem Studies in Latin America and Africa, UNESCO, Paris, 1997, pp. 155-162.

[9] S. Cannicci et al., Predatory activity and spatial strategies of Epixanthus dentatus (Decapoda: Oziidae), an ambush predator among the mangroves, J. Crust. Biol. 18(1) (1996) 57-63.

[10] S. Cannicci et al., Branch-fidelity in the tree crab Sesarma leptosoma (Decapoda, Grapsidae), J. Zoo. 238(4) (1996b) 795- 801.

[11] T.D. Steinke, A. Rajh, A.J. Holland, the feeding behavior of the red mangrove crab Sesarma meinertiDe Man, 1887 (Crustacea: Decapoda: Grapsidae) and its effect on the degradation of mangrove leaf litter, South Afr. J Mar. Sci. 13(1) (1993) 151-160.

[12] J.E. Conde, H. Diaz, Extension of the stunting range in ovigerous females of the mangrove crab Aratus pisonii(H. Milne Edwards, 1837) (Decapoda: Brachyura: Grapsidae),Crustaceana.62(3) (1992) 319-322.

[13] J.E. Conde et al., Nitrogen and tannins in mangrove leaves might explain interpopulation variations in the crabs Aratus pisonii, Acta Cintifica de Venezuela. 46 (1995) 303-304.

[14] D.M. Alongi, Present state and future of the world's mangrove forests, Environmental Conservation.29 (2002) 331-349.

[15] A.O. Numbere, The impact of oil and gas exploration: invasive nypa palm species and urbanization on mangroves in the Niger River Delta, Nigeria,in: C. Makowski, C. Finkl (Eds.), Threats to mangrove forests. Coastal Research Library, 25, 2018, Springer, Cham.

[16] L.D. Lacerda et al., The biogeochemistry and trace metals distribution of mangrove rhizophores, Biotropica. 25 (1993) 252-257.

[17] C. Marchand et al. 2006. Heavy metals distributions in mangrove sediments along the mobile coastline of French Guiana, Mar. Chem. 98(1) (2006) 1-17.

[18] Z.W. Zhang et al., Heavy metals and organic contaminants in mangrove ecosystems of China: a review, Environmental Science and Pollution Research. 21(20) (2014) 11938-11950.

[19] M. Sadiq, T.H. Zaidi, Sediment composition and metal concentrations in mangrove leaves from the Saudi coast of the Arabian Gulf, Science of the Total Environment.155 (1994) 1-8.

[20] N.F. Tam, Y.S. Wong, Accumulation and distribution of heavy metals in a simulated mangrove system treated with sewage, Hydrobiologia. 352 (1997) 67-75.

[21] R.Q. Yu et al., Benthic macrofauna of the mangrove swamp treated with municipal wastewater, Hydrobiologia.347 (1997) 127-137.

[22] F. Bartoloni et al., The effect of sewage discharge on the ecosystem engineering activities of two East African fiddler crab species: consequences for mangrove ecosystem functioning, Marine Environmental Research. 71 (2011) 53-61. 
[23] A.S. Mandura, A mangrove stand under sewage pollution stress: Red Sea, Mangroves and Salt Marshes. 1 (1997) 255-262.

[24] M. Mastaller, Destruction of mangrove wetlands-causes and consequences, Natural Resources and Development. 43-44 (1996) 37-57.

[25] A.O. Numbere, G.R. Camilo, Structural characteristics, above ground biomass and productivity of mangrove forest situated in areas with different levels of pollution in the Niger Delta, Nigeria, African Journal of Ecology. 56 (2018) 917-927.

[26] K.M. El-Moselhy et al., Bioaccumulation of heavy metals in some tissues of fish in the Red Sea, Egypt, Egyptian J. Basic App. Sci. 1(2) (2014) 97-105.

[27] L. Atwell, K.A. Hobson, H.E. Welch, Biomagnification and bioaccumulation of mercury in an arctic marine food web: insights from stable nitrogen isotope analysis, Can. J. Fish. Aqua. Sci. 55(5) (1998) 1114-1121.

[28] M. Al-Busaidi et al., Toxic metals in commercial marine fish in Oman with reference to national and international standards, Chemosphere. 85 (2011) 67-73.

[29] A.C. Bosch et al., Heavy metals in marine fish meat and consumer health: a review, J. Sci. Food Agri. 96(1) (2016) 32-48.

[30] A.E. Gobo, Micrometeorological studies for Bonny environment, African Journal of Environmental Studies.2 (2001) 42-46.

[31] N. Cumberlidge et al., Tree-climbing crabs (Potamonautidae and Sesarmidae) from phytotelmic microhabitats in rainforest canopy in Madagascar, J. Crust. Biol. 25(2) (2005) 302-308.

[32] S.N. Longonje, D. Raffaelli, Feeding ecology of mangrove crabs in Cameroon, Merit Res. J. Environ. Sci. Toxicol. 1 (2013) 99-108.

[33] M.M. Rufino, P. Abello, A.B. Yule, Geographic and gender shape differences in the carapace of Liocarcinus depurator (Brachyura: Portunidae) using geometric morphometrics and the influence of a digitizing method, J. Zoo. 269(4) (2006) 458-465.

[34] K.V. Dhaneesh et al., Bio-accumulation of metals on reef-associated organisms of Lakshadweep Archipelago, Food Chemistry. 131 (2012) 985-991.

[35] A. Aigberua, T. Tarawou, Speciation and Mobility of Selected Heavy Metals in Sediments of the Nun River System, Bayelsa State, Nigeria, Environ. Toxicol. Stud. J. 2 (2018) 1.

[36] M. Logan, Biostatistical design and analysis using R: a practical guide, John Wiley and Sons, England, 2010.

[37] R Development Core Team, R: A Language and Environment for Statistical Computing. R Foundation for Statistical Computing, Vienna Austria. http://www.R-project.org. (2013).

[38] G.N. Anaero-Nweke et al., Heavy Metal Levels in Water, Sediment and Tissues of Sarotherodon melanotheronfrom the Upper Bonny Estuary, Nigeria and Their Human Health Implications, Int. J. Mar. Sci. 8(23) (2018) 186-194.

[39] FAO/WHO (Food and Agriculture Organization/World Health Organization), A model for establishing upper levels of intake for nutrients and related substances, FAO/WHO Nutrient Risk Assessment Workshop, May 2-6, 2005, WHO Headquarters, Geneva, Switzerland, (2006) 182.

[40] P.G. Smith, The ionic relation of Artemia salina (L). II Fluxes of sodium, chloride and water, J. Exp. Biol. 51 (1969) 739-757. 
[41] A. Soegianto et al., Impact of copper on the structure of gills and epipodites of the shrimp Panaeus japonicas, J. Crust. Biol. 19 (1999) 209-223.

[42] C.A. Foster, H.D. Howse, A morphological study on gills of the brown shrimp, Panaeusaztecus, Tissue Cell. 10 (1978) 77-79

[43] P. Compere, J.A. Morgan, G. Goffinet, Ultrastructural location of calcium and magnesium during mineralisation of the cuticle of the sohore crab, as determined by the K-pyroantimonate method and X-ray microanalysis, Cell Tissue Res. 274 (1993) 567-577.

[44] T.O. Genc, F. Yilmaz. Bioaccumulation indexes of metals in blue crab inhabiting specially protected area Koycegiz Lagoon (Turkey), Indian Journal of Animal Science. 85 (2015) 9499.

[45] B.P.D. Batvari et al., Heavy metals accumulation in crab and shrimps from Pelicat Lake, north Chennai coastal region, southeast coast of India. Toxicology and Industrial Health 32(2016) $1-6$.

[46] P.R. Henry et al., Multiple function of crustacean gill: osmotic/ionic regulation, acid-base balance, ammonia excretion, and bioaccumulation of toxic metals, Front. Physiol. 3 (2012) 431.

[47] A.J. Gutierrez et al., Heavy metals in black crabs in the Atlantic Coast (Tenerife, Spain)Human risk assessment CLEAN-Soil, Air, Water. 45 (2016).

[48] J.I. Spicer, R.E. Weber, Respiratory impairment by water-borne and zinc in the edible crab Cancer pagarus (L) (Crustacea: Decapoda) during hypoxic exposure, Marine Biology. 33 (1992) 9-26.

[49] E.M. Amado et al., Lead hampers gill cell volume regulation in marine crabs; stronger effect in a weak osmoregulator than in an osmoconformer, Aquatic Toxicology. 106-107 (2012) 95103. 